\title{
WHO RULES INDIA? A FEW NOTES ON THE HINDU RIGHT
}

\author{
Tanika Sarkar \\ Jahawarlal Nehru University, Delhi
}

\section{Abstract}

Hindu extremism captured state power in India in 2014, and, at present, it controls a large number of regional states as well as leading the ruling coalition at the Centre. This has led to significant and wide ranging changes in Indian polity and in political norms and values, and the first part of my article will briefly indicate their range, immediate consequences and long term implications. I will outline the historical evolution, and unpack the structural distinctiveness, of the Hindu Far Right to explore its mobilisational strategies and its ideological agenda over nine decades. In the final part, I will focus on two specific sites of violent hate crimes against religious minorities and against freedom of individual and collective thought and choice.I will finally try and explain their relevance to the larger agenda of the Hindu Right and their broad direction.

Keywords: BJP, Dalits, Extremism, Hindutva, Love Jihad, RSS.

\section{RESUMEN}

La extrema derecha hindú llegó al poder en India en 2014 y en la actualidad controla un buen número de estados de la Unión, además de ostentar el gobierno federal. Esto ha contraído una serie de cambios en las reglas del juego político en el país. La primera parte de mi artículo indica el alcance de este poder, sus consecuencias inmediatas y aquellas otras a largo plazo. Haré una semblanza histórica del extremismo hindú, así como del desarrollo de su estructura a lo largo de nueve décadas. Finalmente me centraré en dos casos instigados contra las minorías religiosas y la libertad de pensamiento y elección, explicaré su relevancia en los planes de la derecha hindú y el lugar que ocupan en su estrategia.

Palabras Clave: BJP, Dalits, Extremismo, Hindutva, Jihad matrimonial, RSS.

DOI: https://doi.org/10.25145/j.recaesin.2018.76.16

Revista Canaria de Estudios Ingleses, 76; April 2018, pp. 223-239; ISSN: e-2530-8335 
Something strange and momentous is now unfolding in India. Built on deep historical roots, it became overwhelming from 2014, when the Bharatiya Janata Party, (BJP) representing "Hindutva"1 or Hindu extremism, captured state power, winning an absolute majority of Parliamentary seats. ${ }^{2}$ The unique hallmark of the $\mathrm{BJP}$ - that which sets it apart from other parties — is their long and single-minded history of activating antagonism towards non Hindus (especially Muslims), and a proclaimed ideology of redefining secular, multicultural India as Hindu Rashtra or Hindu nation. ${ }^{3}$ In the process, a significant restructuring of the Hindu faith also happens as some of Hindutva's imperatives enter the religious world view of a large number of Hindus.

I will begin with a brief discussion of their discursive strategies, organizational structure and ideological apparatus. The first two are as intricate, innovative and deft as their ideology is thin and one-dimensional. The former clearly substantiates and empowers the latter and allows it wide dissemination. I will then shift to current events, focusing, especially, on two critical sites: violence over the cow, and violence against love between Hindus and Muslims.

A few words about the present context, to begin with. Colonial India was partitioned in 1947 when large numbers of Muslims migrated to Pakistan. Consequently, Muslims in India were reduced to a small numerical minority —as, indeed, were non Muslims in Pakistan: without strong political clout or national —level parties of their own. ${ }^{4}$ In social, economic, educational and professional terms, too, they have lagged far behind rich segments of upper and dominant caste Hindus. ${ }^{5}$ Conflicts between religious communities changed radically as a result, turning erstwhile riots into virtual pogroms by the 1980s. (Vanayak 2007).

Given the staggering numerical preponderance of Hindus, Hindutva appropriates the mantle of representing India, since it claims to represent Hindus. It

${ }^{1}$ Hindutva is their self designation, a term coined by V.D Savarkar in 1923 which claimed that it referred to the cultural essence of Indian nationhood. We will discuss this later. It is different from Hinduism as religious faith and embodies an authoritarian nationalism which claims to represent the community of Hindus as the only authentic Indians.

2 There has earlier been another BJP-led coalition government at the Centre between 1998 and 2004. The BJP has ruled over several regional states as well and their numbers are steadily growing. The scale of victory in 2014 has however been staggering, giving Prime Minister Modi almost unlimited power. About $30 \%$ Hindus voted for Modi as a large bloc.

${ }^{3}$ In practice, secularism has often been compromised, and not always by the BJP. But it is a constitutionally enshrined pledge which is now being mocked and subverted openly.

${ }^{4}$ According to the 2011 Census, Hindus constitute an overwhelming $79.80 \%$ of the total Indian population, Muslims are $14.23 \%$ and Christians are $2.3 \%$.

5 This is abundantly demonstrated by the 2011 Sachar Committee Report on the Status of the Minorities. 
flaunts itself as the nationalist force par excellence, closing down the necessary gap between religious community and nation, between majoritarianism and nationalism.

Partition, moreover, was achieved amidst horrific violence between Hindus and Muslims: killing thousands and displacing millions from their homes and country, and leaving a legacy of bitter, hate-filled memories, lasting fear and suspicion. Though casualties were precisely equal on both sides, Hindutva forces have always maintained that Hindus were the sole victims (Sumit Sarkar 1983: 434). ${ }^{6}$ Instead of trying to overcome hostility with peace, they determinedly foment anger and manufacture memories and histories of Muslim atrocities. Several wars with Pakistan, conflicts over the possession of the erstwhile independent kingdom of Kashmir, and, more recently, terror attacks, ${ }^{7}$ are inserted into a seamless narrative of Islamophobia: wherein Indian Muslims are made to stand in for Partition rioters, contemporary terrorists, and even for medieval Muslim imperial dynasties: as wreckers of temples, abductors of Hindu women and killers of the sacred cow.

The difference between history and myths is being painstakingly erased - with media products, takeover of research institutions and universities, and with new textbooks and journals. In their "history," mythological demons are equated with Muslims, locked in mortal combat with Hindu deities and heroes. ${ }^{8}$ Leftists, despite their rich record of anti imperialism and of colonial repression, are branded as traitors to the nation because of their international solidarities. The Vishva Hindu Parishad (VHP) calls them anti-national and "foreign," along with Muslims, Christians and cosmopolitan liberals (Basu et al. ch 2) Muslims, however, remain the primary targets.

Having constructed an awesome enemy figure, Hindutva then demands perpetual vengeance on present-day Muslims. Hindus are told, moreover, to refashion themselves in the image of the enemy — to be infinitely fanatical, cruel, lustful-so as to worst the imagined Muslim at his own game. The first step, therefore, is to construct a serviceable image of the Other, and then recast the Self in that mould. Inaugural offence is always ascribed to the enemy, and, thereby, everlasting legitimation and benediction are bestowed upon all subsequent offences inflicted by the Hindutva self, no matter how ruthless or unilateral.

What gives the discourse its persuasiveness is a judicious and extremely skillful blending of a few carefully-edited truths, half-truths and blatant misinforma-

${ }^{6}$ In Punjab, in the north, for instance, by March 1948, six million Muslims and four and a half million Hindus and Sikhs had become refugees, the Muslims outnumbering others considerably.

7 The last large scale attack was in 2008, at Mumbai. Interestingly, Pakistan faces far more numerous and continuous terror attacks by "Islamicist " forces.

${ }^{8}$ The medieval emperor Babur was accused — without any foundation — of destroying the supposed birthplace of Lord Ram, a mythological warrior and a sacred figure, and building a mosque in its place. A bloody campaign, accompanied with numerous riots, was undertaken by the VHP, ably assisted by the BJP-Rashtriya Swayam Sevak Sangh (RSS), between 1986 and 1992. The historic mosque was demolished in 1992. In the process, present-day Indian Muslims were characterized in Sangh propaganda as "children of Babur," hence inveterate temple destroyers, who must choose between Pakistan and the graveyard. 
tion. Since there are just a few nuggets of valid information in what they say, that suffices to validate the entire mosaic and lend it credibility. For instance, like all emperors, including ancient Hindu ones, some Mughal emperors too were despotic and sometimes tyrannical. Or, many Muslims did kill and rape Hindus during partition riots, even though many Hindus killed and raped Muslims as well. By excising those uncomfortable parts, and stitching up the residue with manufactured "histories," a toxic mixture is produced which convinces people about the need for violence here and now. History therefore is Hindutva's critical weapon, a veritable battlefield of contested meanings, since present-day Indian Muslims — suffering from multiple vulnerabilities - hardly offer convincing grounds for violent attacks.

The BJP Founded in $1980^{\circ}$ is the electoral wing of a much larger and older institutional complex, calibrated by the apex body, the Rashtriya Swayam Sevak Sangh (RSS, founded in 1925). The religious front or the Vishwa Hindu Parishad (formed in 1964) aspires to unify all major Indian and global Hindu sects, establishments, temples and priests under the Hindutva rubric. They have, indeed, gone a long way in that direction. They control the Sanatan Dharm Mandir complex of temples - the largest temple chain in North India-, conduct annual conclaves of leading religious heads and ascetics, and train domestic priests who have enormous influence within households (Tanika Sarkar 2012). Their global reach among nonresident Hindus is immense. Mass fronts have their own affiliates and sub-affiliates which are truly legion, their full scope and numbers being as yet unknown. All important mass fronts have been founded by the RSS. (Jaffrelot 2005).

The RSS trains leaders for all these fronts at shakhas or daily meetings which provide combat and ideological training, and members can simultaneously belong to several fronts. It oversees the general policies of the mammoth, multifaceted combine (Vanayal 1990). ${ }^{10}$ The structure has overlapping parts and the system of simultaneous and multiple front-membership bestows coherence and integration on the complex organism, despite some factional differences from time to time, within and between different fronts (Jaffrelot 2005). Prime Minister Narendra Modi has always been an RSS member -indeed, he was, for a long time, a Pracharak, committed to celibacy and to fulltime teaching of the RSS message. So have been a past BJP prime minister and almost all its present top ranking leaders.

The Sangh has been working for ninety-two years, since 1925. Shakhas, set up first by K.B. Hedgewar, expanded significantly when M.S. Golwalkar became the supreme leader of the Sangh in 1940. From the beginning, they adopted a "catch

9 Its predecessor, the Bharatiya Jana Sangh was formed in 1951.

${ }_{10}$ On the structure of this most complex combine, see the excellent collection of essays in C. Jaffrelot, ed, 2005; T. Basu et al., 1993. 
them young" perspective. Very young boys who came to them - mostly upper caste, middle class, urban and, initially, only brahmans or the "purest" caste- were attracted by a combination of open air games and physical cum combat training, a peer group to play with. Parents were attracted by the shakha discipline.

Once into the fold, boys learn three lessons on a daily basis. First, Hindu pride: Hinduism as the greatest religion of all, source of world civilization and knowledge, and Hindus as a community of virtuous heroes. Second, hatred against Muslims who are presented as conquering, exploiting and trying to destroy Hindus throughout history. Antagonism, apparently, is an ingrained Muslim characteristic, and nothing can ever change it.

Above all else, they are taught that India is the land of Hindus because their places of worship alone are contained within Indian territories. At one stroke, Muslims and Christians - a part of the country for many centuries - are rendered alien, and, hence, dangerous, to the nation (T. Basu et al. ch. 1). V.D. Savarkar, ideological guru of the Sangh, laid it down very clearly in his seminal tract of 1923 Hindutva: Who Is A Hindu ? He also said that Indian history consists solely of Muslim invasions and of Hindu struggles to retain their rightful territories. This iconic text was written at a time when southern and western India were rocked by "lower" caste protests and challenges to brahmanical power. Savarkar had to reckon with them and refer to caste divisions among Hindus. He claimed that divisions have long been superseded by miscegenation and mixing of blood among castes. All Hindus, he said — gross inequalities notwithstanding — share primeval family ties, based on common blood.

But even the metaphor of blood was not enough to procure Hindu unity. So he invoked the Muslim. "Nothing makes Self conscious of itself so much as a conflict with non-self. Nothing can weld people into a nation and nations into a state as the pressure of a common foe. Hatred separates as well as unites" (Jaffrelot 2007: 91-92). A Hindu nation that wants to mask power lines internal to Hindu society, needs an external threat to actualize unity. Hatred is foundational to the nation.

In 1938, Golwalkar, second supremo of the Sangh, spelt out the implications with admirable clarity:

To keep up the purity of the nation and its culture, Germany shocked the world by her purging the country of the semitic races... Race pride at its highest has been manifested here... all the constituents of the Nation idea have been boldly vindicated in modern Germany and that, too, in the actual present, when we can for ourselves see and study them... a good lesson for us in Hindustan to learn and profit by...' The Nazi lesson for India was 'they (non-Hindus) may stay in the country wholly subordinated to the Hindu nation, claiming nothing, deserving no privileges... not even citizen's rights. (Golwalkar ch 3)

No Sangh constituent has ever retracted this profusely reprinted and much used statement.

But a new danger threatened to undermine the pursuit of unity- withhierarchy. In his early life, Savarkar had participated in violent attacks on British officials. From his exile at the Andaman Cellular Jail, however, he appealed piteously 
to British authorities to give him a second chance since he realized his error. Now that Gandhi had begun a mass movement against the British, hand in hand with anti colonial Muslim Khilafatists, he could see how necessary the Empire was. He promised that, if released, he would oppose Hindu-Muslim unity as best as he could, and devoutly serve the "Aryan Empire" of the British which stretches from Ireland to India. He was released and he kept his word (Jaffrelot 2007: 91-92).

British imperialism is rarely criticized by the Sangh with anything like the fervor that is reserved for the Mughal Empire - except as an enabler of Christian missionaries who are the butt of very angry attacks. British rulers appreciated this. Otherwise extremely wary of armed training among political groups, they never exercised repression against the RSS. The RSS alone has the dubious distinction of never coming under a ban under the British, even at peak moments of colonial repression.

Members were meant to undergo a full scale physical and ideological reshaping in shakhas. This was RSS "man making" — a step by step, person by person advance, a molecular expansion agenda. Only after that can "nation making" happen effectively. Growth was impressive, in quantitative as well as in geographical terms. But the social spread, for quite some time, was largely restricted to upper and dominant caste, urban middle classes, which even now remain their most assured support base. In 1939, there were 40,000 RSS members and 500 shakhas. In 1948 , they grew to 600,000 volunteers or swayamsevaks as partition had inflamed Hindu anger. Shakhas jumped from 10,000 in 1977 to 13,000 in 1979, and swayamsevaks crossed the 1 million mark. By 1989, there were 25,000 shakhas and 1.5 million volunteers. By 2004, there were 33,758 shakhas and 48,329 upshakhas or sub branches (Jaffrelot 2005: 3-5).

The RSS is an all-male organization, but in 1936 a women's branch (Rashtrasevika Samiti) was formed to provide identical training to like — minded women, drawn largely from RSS families. Coming from extremely orthodox and patriarchal social backgrounds, they found a release in the shakha, a public role, and a political mission that gave them some self-esteem and respect in their homes. But the new identity, however empowering to themselves, never challenged the broader values of domesticity, obedience to male guardians and a subordinate role, at home and in the RSS world. In 1999, a member told me that their preeminent task is to discuss and "interpret" current news in informal circles of family, kin-group, neighbours and at workplaces. Above all, their pre-school infants have to be firmly oriented to Sangh values and messages (T. Sarkar and Butalia 1995; Bachhetta 1996; T. Sarkar 1999; Tyagi 2017). At home, they practice a conservative domesticity which is hostile to divorce, and to love that is not sanctioned by parents. They advise women that domestic peace is their responsibility and they avoid counselling or legal help for battered women on that ground.

At the same time, they do create a new woman at shakhas: physically strong and trained, politically motivated and confident (T. Sarkar 1995: 181-215). It is somewhat difficult to identify their precise location within the Sangh structure. Like women of the Ku Klux Klan in post-bellum US, they run whisper campaigns in homes, alerting women to the dangerous enemy and preparing them to assist 
their men in reprisals. (Blee 1991). On the other hand, among women's branches of the VHP, the training is markedly more militaristic and combative. Nisha Pahuja documentary The World Before Her (2013) shows very young VHP girls picking up guns and asking when they can use them against Muslims: and saying how scrupulously they avoid Muslim schoolmates. Prachi, who trains them, has huge anger against Muslims. Her VHP father proudly recalls how he had physically tortured her - branded her with red hot iron- when she was only seven for telling a minor lie. She is not angry with her father since he was "only doing his duty." Rather, she adores him because he did not kill her at birth even though she is a daughter and not a son. The social values and expectations within a milieu that breeds Hindutva women like her are, thus, already brutalized.

The Sangh combine has sent down roots into all spheres of social, political and cultural lives, into the everyday world of Hindus: founding fronts and cells among religious establishments, leisure and cultural activities, trade unions, students and teachers, peasants and tribals, urban slums, education (they run the largest chain of non-governmental schools in the country), Army, media and lawyers - to name just a few activities. With a chain of Vanvasi Vikas Ashrams, they pay special attention to tribals or indigenous people - extremely marginalized, often evicted and pauperized through corporate land grabs, and lacking the means to any upward mobility, apart from Christian mission schools which have done much to spread education among them. To counter Christian influence, RSS schools for tribals -Ekal Vidyalays which meet weekly with one teacher - have been set up among them in very large numbers. Significantly, they mostly teach the worship of Hindu gods and myths, and the full educational apparatus of other schools is withheld. Schools, trade unions, shakhas and other institutions preach a single social message: that order must be maintained, social harmony, and not class or caste conflicts, should be promoted, and the concept of subaltern rights must be eschewed in the interest of their duties towards the nation and the community. ${ }^{11}$

The Sangh combine has, therefore, achieved what no other party has come even close to. The very capillaries and pores of civil society, their spaces and times, have been penetrated over a long period of time, by an enormous cadre base that works tirelessly, selflessly, with total commitment, mostly with meager rewards, often in remote and difficult areas: only to propagate hatred and cultural arrogance.

Modi's victory unleashed dramatic and sweeping changes in economy and polity, in ethical and cultural values, across a country hitherto known as the world's largest democracy. Democracy, however, is conditional on equal citizenship rights,

${ }^{11}$ For the various branches of the Sangh combine, see articles by Jaffrelot, Manjari Katju, Tanika Sarkar, Thomas Blom Hansen, and Kiran Saxena in Jaffrelot 2005. 
whereas Hindutva insists that India belongs to Hindus alone. Self-immolation and inviolate chastity are emphatically valorized as supreme markers of a good woman, historical facts are made to bow before Hindu legend, and a cruel dismissal of pain as well as of medical science becomes possible in the name of Karma.

These facts give the lie to a persistent global myth: that even if Hindutva had embodied violent intolerance in the past, ${ }^{12}$ now, under Modi, it represents economic reforms and development, an eager embrace of global investment, and a growing global credit-worthiness. Hindutva-archaic has, apparently, given way to Hindutva-modern. Global corporate investors are happy to endorse this view as Modi has substantially undermined existing social and environmental safeguards for the land and livelihood of the poor in order to help multinational capital. Our three examples, relatively "mild" as they are, show that the split is an imagined one.

I call these events innocuous because our daily news fare usually consists of ferocious violence and sinister intimidation. I will leave out the "states of emergency" which have obtained for decades in Kashmir and in the North East altogether, or the "encounter killings" by police, paramilitary and armed forces. ${ }^{13} \mathrm{I}$ will also not discuss the frequent imprisonments of innocent Muslims on unfounded charges of terrorist conspiracy — only to be released decades later when they could not be substantiated (Khan and Haksar, 2016).

Nor will I go into church burnings, rapes of nuns, eviction of thousands of Christians who were forced to live in makeshift camps for years in Orissa in a state of siege (Mathur 2008; Chatterjee 2009). Four distinguished critical journalists, rationalists and atheists, men and a woman, young and very old, have been assassinated since 2013, for attacking popular superstition, or distortions of history: Narendra Dabholkar, killed in August, 2013, Govind Pansare, in February, 2015, M.M. Kalburgi, in August, 2015, and Gauri Lankesh, in September, 2017. The BJP disclaims responsibility, but it is significant that all were highly critical of Hindutva ideology and their own rationalism and atheism would be profoundly repugnant to

12 From 1986, a nationwide campaign to demolish a $16^{\text {th }}$ century mosque in the northern town of Ayodhya and build a temple to Ram, an epic hero and Hindu sacred figure, was undertaken amid huge anti Muslim pogroms all over the country. The mission was bloodily accomplished in 1992. The 1990s saw a heightening of majoritarian violence against Indian Muslims and Christians: the most tragic ones being the burning alive in 1998 of an Australian social worker, Graham Staines and his small sons in Orissa, as he was suspected of converting local tribal groups, and genocidal aggression in Modi-ruled Gujarat in 2002 that finished off about 2000 Muslims in a few days and led to many rapes and mutilations.

${ }_{13}$ On the recent extra judicial killings of Muslim youths in "encounters" with the police and on custodial killings see Harsh Mander 2007. 
Hindutva ideas. ${ }^{14}$ Young people who campaign for social and environmental justice, for civil liberties, are branded as "anti national," and charged with sedition. ${ }^{15}$ At the University of Hyderabad, a young, poor and extremely promising Dalit student, Rohith Vemula, had his fellowship stopped for engaging in protests in defence of civil liberties. In despair, he committed suicide on 17 January, 2016. The government made offensive statements about his family and his real intentions. ${ }^{16} \mathrm{I}$ will discuss ordinary, banal, and everyday happenings instead, focusing on two particular sites of recent Hindutva activism: cow vigilantism and so called Love or Romeo Jihads.

Between 2015 and September 2017, there have been 24 recorded hate attacks, almost all against Muslims, leading to thirty four murders and two rapes and many floggings, on the pretext of cow killing or beef eating: mostly in the BJP-ruled states of Haryana, Uttar Pradesh, and Jharkhand. But these are now spreading into eastern parts as well: in Assam — now ruled by the BJP — and in West Bengal. Numbers have gone up since September.

About $94 \%$ of the killings are attributed to groups directly affiliated to the Sangh: the Bajrang Dal which is the youth wing of the VHP, the VHP, or other affiliates. Marauding mobs call themselves cow protectors or Gau rakshaks. Untouchable caste people or Dalits (they call themselves by this name which means "oppressed") are publicly flogged and humiliated. At Una in the western state of Gujarat, ruled by the BJP for three successive terms, seven Dalit youths were beaten up with iron rods in July 2016 for skinning a dead cow. They were then paraded half naked in public and beaten all the way to the police station ("Citizens" 2017). Lynchings such as this one have sometimes been filmed live and circulated widely in the social media. But that did not deter the killers, sure as they were, of public and state approval. Nor did visual evidence produce noticeable state reprisals.

Beef eating is prohibited in several Indian states because it is offensive to upper caste Hindus who regard the cow as holy: as a mother figure. Large segments of "lower castes" have imitated them over the years to gain social respectability. For Muslims, on the other hand, cow sacrifice is a sacred annual ritual and neither Muslims nor Christians are under religious restrictions against beef eating. The one sided restrictions - as piggery products, offensive to Muslims, are not prohibitedhave always qualified full secularism which India formally espouses.

Many Muslims are farmers, cattle traders or breeders, while segments of Dalits are poor leatherworkers, engaged in skinning dead cows for hide. Layers of subaltern livelihood depend on cattle trade, disposal of sick or dead cattle, skinning cattle for hide. All have become pretexts for lynching. Panic is now so great that

${ }^{14}$ On Gauri Lankesh's writings on Hindutva, see Khalid 2017.

15 This happened to students of Jawaharlal Nehru University, a premier Central university on 9 February, 2016 with the help of clearly doctored videos to prove that they were shouting antinational slogans. The Delhi High Court found the evidence inadequate and they are now out on bail. One student was flogged by lawyers and a BJP Member of Parliament before TV cameras. See The Indian Express, 10 February to 30 March issues, 2016. Also Lawrence Liang 2016.

16 "Rohith" 2017. 
Muslims fear to dispose of dead or sick cows, to drive out stray cattle from their fields when they eat up the crop, or transport cattle for commercial purposes - lest they be accused of intending cow slaughter. A Muslim found with any kind of meat product is often accused of beef eating and then lynched before the facts can be established. ${ }^{17}$ So-called cow protectors make a good picking out of raids and extortion, and unchecked lynching of helpless victims becomes an intoxicating pastime. At the same time, bloodlust is cloaked under a religious mission: in their own eyes, and in the eyes of many Hindus, they are saving the holy cow. The ruling party — when under pressure from global media reportage or from protests in India- dismisses this as the work of anonymous, unaccountable criminal gangs or mobs.

The fig leaf of cow protection sometimes collapses when Muslims - not even accused of carrying/trafficking/ consuming beef- are killed, just because they are Muslims, going about their own business, without any possible offence to anybody. In June this year, Junaid Khan, a 15 year old Muslim boy, was abused and then knifed to death by middle-class, professional Hindus on a train, simply because he was a Muslim. His relative was also brutally flogged. When the bereaved family demanded that the Central Bureau of Investigation investigate the murder, the Punjab and Haryana High Court dismissed the plea, saying it has no national or international importance whatever.

The tolerance threshold for communalized ${ }^{18}$ criminality has obviously gone up enormously, creating what may be called a "new normal." New areas of violence open up endlessly, blocking any considered response or even a full understanding, of the total picture. What seemed an intolerable violation of democratic-human norms yesterday, is surpassed by far greater ones today, and the past infringement gets normalized as yet another "new normal" keeps forming daily. This is what Naomi Klein (2008) calls "shock doctrine" — used when a new regime introduces seismic systemic transformation and wants to keep the nature of changes opaque.

Significantly, these happen in broad daylight, on crowded highways and roads, and are made known to everybody by the media. Junaid Khan was killed on a crowded train. No one came to his help. Pehlu Khan was killed on a highway in May 2017, and Alimuddin Ansari on a busy street in July 2017 ("Citizens"). Lynch mobs clearly operate on a very wide consensus.

There is terrifying police silence, even active complicity, in BJP-ruled states. First Information Reports by survivors or their families are sometimes not accepted at police stations or are wrongly drafted there, allowing assailants release on bail on easy terms: as happened after the murder of Akhlaq Khan in June 2015. Witnesses and survivors are threatened and silenced openly, as happened in the lynching of Hazloom Ansari and others in May 2016. The police drags its feet about submit-

${ }^{17}$ New laws, however, are changing the situation. A wave of new rules appeared in 2015, against beef consumption. See Radha and Amar Sarkar 2016.

${ }^{18}$ From colonial times, the term "communalism" in India has indicated ethnic strife and hatred between religious communities. 
ting charge sheets to magistrates within the stipulated time frame, as happened in the cases of Mustam Abbas in March 2016 and Ibrahim and others in August 2016. The delay undermines the cases. If ever there is a trial, it drags on indefinitely, and in two years, only one verdict has appeared so far . For victims, dead or alive, compensation is a distant and unrealistic dream. In cases of murder, they receive a nominal ex gratia relief, if at all: as happened with the family of Mazloom Ansari or Alimuddin Ansari in March 2016 and July 2017 ("Citizens"). The media soon gets engrossed in assessing if the slain Muslims ate or carried beef. They point the finger of suspicion at the victim, not at perpetrators.

A few things stand out from this bald summary. First, violence is partly legitimized by a horizon of religious values where the cow is supremely sacred. Given that, the fact that Muslims consume beef - which involves cow killing - immediately makes them the Other of Hindus. In Hindutva propaganda, it is the religious mission of Muslims to destroy Hindu holy beings: ergo, Islam has to destroy Hinduism - a conviction much fattened by rumours and legends of past Muslim rulers forcing the Hindu to eat beef and the good Hindu choosing death to that. So, in Hindutva logic mob lynching of Muslims gets translated as a struggle for Hindu survival.

Since the destruction of Muslim lives happens in the name of the holy cow, it blocks a sufficiently strong horror about lynching among many Hindus. They may not themselves join the lynch-mob but neither would they do anything to stop it. Cow-communalism has, moreover, old roots. In the late $19^{\text {th }}$ century, Hindus and Muslims had clashed over cow slaughter in several parts of northern India (Pandey 1990). Shortly after the birth of the VHP, a band of ascetics came out on Delhi streets in 1966, rioting to demand a total ban on beef and cow killing (Basu and Sarkar ch. 1).

Hate attacks involve a visible defiance of democratic political values and norms. These have, of course, been violated earlier, too, by the powerful and the privileged. But then the acts were covert and insidious, rather than open and demonstrative. Without an explicit overturning of the established constitutional framework based on a secular democracy, we have now reached a stage where state institutions as well as large sections of the Hindu public have accepted majoritarian authoritarianism, however much violence that involves.

\section{IV}

At a recent VHP-organized apex meeting of Hindu sectarian heads and ascetics, religious leaders demanded that all regulations against cow vigilantism be done away with. Their authority is immense and no doubt their call will be heeded soon.

They demanded something else as well. They asked the VHP to train Bajrang Dal youths in the art of seduction so that they can attract and annex Muslim girls to the Hindu community. They call this "save the daughter and bring in the bride": that is, keep the Hindu daughter within the Hindu fold, and bring in a Muslim daughter - in-law from outside. The rationale? A conviction, produced by the RSS propaganda machinery, that Muslims are politically motivated to abduct Hindu 
women by pretending love for them: to destroy their precious purity and honour, to contaminate their wombs with Muslim progeny, and add to the Muslim population, so that Muslims overtake Hindus in numbers and turn India into a Muslim land. Love of a Muslim man for a Hindu woman is a mere mask to achieve through sexual conquest what terrorists and Pakistan aim to do. It is war by other means. Hindus, therefore, are obliged to retaliate in kind.

Hence the name anti "Love Jihad" or "Romeo Jihad" (the latter coined by Mohunt Adityanath a monk, recently made Chief Minister, Uttar Pradesh) for campaigns opposing cross community love. Shanthakaka, leader of Rashtrasevika Samiti, alleges that Muslim boys are paid handsomely if they elope with Hindu girls. Payment, apparaently, varies according to her caste. For a Rajput girl, they get Rs.1 lakh (about Euro 1,245) while the amount doubles for a brahman girl, from the "purest" caste. The Muslim lover is, above all, bent on blackening "pure caste" pride and honour (Dixit 2014; Bhatnagar 2015).

Rumours of Muslim abduction of Hindu women had fuelled communal violence since at least the 1920s. Savarkar wrote tomes on medieval history, arguing that Muslims invaded India in the past to enjoy Hindu queens whom they conquered and raped. Hindu kings, being chivalrous by nature, avoided that strategy - a mistake, Savarkar said, because this encouraged Muslims to indulge in rapes undeterred. (Agarwal 1995).

Usually, such a couple elopes and her parents then approach the VHP and a highly accommodating police force. They arrest the man, force the woman back to her parents who, in turn, force her to issue a public statement, saying that she was coerced to elope, marry and convert. Grisly tales of Muslim lust then go viral on the media. Surprisingly, in court, the woman almost always retracts her statement, saying that she was made to lie by family and police. Since 2014, attacks on intercommunity love have proliferated rapidly (Dixit 2013; Dixit 2014).

In a recent case, a twenty-four year old girl, who was born a Hindu (Akhila, now renamed Hadiya) converted to Islam and then married a Muslim man. The Kerala High Court annulled the marriage arbitrarily when her parents opposed it, even though she has consistently and repeatedly asserted that conversion and marriage were her own free decision. The court alleges, instead, that such acts are often achieved by Muslim brainwashing. So far the Supreme Court, which is still pondering on the validity of her conversion and marriage, has put her under a number of restrictions, even though she is an adult who has expressed her will in the strongest possible terms. If she has been removed from the custody of her parents who systematically intimidated her, it still does not allow her to live with her husband (Krishnan 2017). A teen-aged couple, a Hindu girl and a Muslim youth, were murdered in Bihar, in a recent case of honour killing by the girl's family.

Indeed romance itself, when unsanctioned by family, is altogether under a dense cloud. There are highly organized roadside attacks on courting couples by Hindu extremist outfits, travelling on motorcycles, and calling themselves antiLove Brigades: inflicting terror on non marital love which may not even be intercommunity. Self-styled Anti Romeo Squads, composed mostly of women, and aided by the police, harass and humiliate courting couples in public, especially in small 
towns. A BJP woman Member of Parliament, Sangeeta Varshney, slapped a Dalit woman in public for going out with a Muslim man. Filmed, this was splashed on the social media and, three days days later, the police were forced to enter a complaint that her father lodged. Such a supportive father is extremely uncommon. The BJP is the only Indian political party which opposes the legalization of non-heterosexual relationships.

On the other hand, a BJP Government affidavit opposed petitions asking for criminalization of marital rape which were submitted to the Delhi High Court by rape victims. Unless the woman is below 15 years of age, these rapes are not criminal offences under Section 375 of the Indian Penal Code. The government argued that what "may appear as marital rape to a wife may not appear so to others ... would disturb the institution of marriage apart from being an easy tool for harassing the husbands" (Nair 2017). Force is thus legitimized whereas love is not, and the wife's wishes are expendable if "others" sanction conjugal violence. Harassment of the husband is clearly a more serious offence than the wife's rape.

Hindutva claims that Hindus and Muslims do not share a common humanity. Love between them, therefore, is unnatural. A Delhi VHP leader told us in 1990 that their men routinely scour registry offices to scan marriage notices that have to be put up in advance. If they find an announcement of an intercommunity marriage, they ask the parents whether they know and approve of it. If they are not agreeable, they try to block such marriages and, if they are, they try to dissuade them. ${ }^{19}$ He went into a long and grisly account of Muslim lust from which Hindu female purity must be saved at all costs. A Rashtrasevika Samiti leader told me 1999: 'They [Muslims] have always raped us, now we must rape them' (Sarkar 2005). In the same sentence she became the raped and the rapist: occupying a doubled sexual identity and easily changing gender, so intense is her wrath against the Muslim. If all Muslim men are genetically coded as rapists — as indeed they are alleged to be, with great force and visceral content in Hindutva narratives, old and new- then love for a Hindu girl must be, in this logical conundrum, the prelude to force. But there is more to it.

Mohunt Adityanath said that such love is actually an international conspiracy'. A VHP woman from Bhopal unpacked the notion to a research scholar who interviewed her in 2016. ${ }^{20}$ The conspiracy, she said, originates in Pakistan, which sends terrorist emissaries to India to train Muslim youths in seduction. They pretend to love innocent Hindu girls and elope with them. They are then converted to Islam. There is also a parallel narrative with a difference, wherein the girl is abducted and forced to marry and convert. Either way, after marriage she is forced to bear Muslim children, to provide slave labour to the entire family as well

19 Between 1990 and 1993, I, along with Sumit Sarkar, Sambudha Sen, Tapan Basu and P.K. Datta, were collecting material for what was later published as Khaki Shorts.

${ }^{20}$ I am grateful to Anshu Saluja, a PhD student at the Centre for Historical Studies, Jawaharlal Nehru University, for sharing her interview experience with me. 
as sexual services to male relatives of her husband. She is then supposedly trafficked to Muslim countries. So we have a dual beginning, in either fake love or in force. Both are projected as typical elements of the Muslim male personality since older historical times.

Significantly, prohibitions are lowered when a Muslim girl marries a Hindu man since demographic calculations get reversed in such cases. Demographic anxieties are, moreover, constantly stoked by a strange Hindutva arithmetic which is widely believed. Each Muslim man apparently marries four wives, as polygamy is allowed under Muslim Personal laws - even though Censuses show that Hindus also practice polygamy. Each Muslim man then breeds at least twenty children at a time, whereas, Hindus, condemned to monogamy by their Personal Law reforms after Independence, produce far fewer numbers. The arithmetic overlooks the fact that no matter whether four women are impregnated by four different men or by one man, each will bear only one child at a time: so, neither monogamy nor polygamy makes the least bit of difference to the number of children that a woman can have.

Love Jihad is a neologism which subverts the meaning of love. Romeo Jihad is a stranger neologism since Romeo is, for the whole world, the iconic figure of doomed, tragic love. Why, then, use his name to castigate inter-community love? It seems that in both cases, lovers defied parental decisions. That becomes a crime and a sin, punishable by violence. If the words are new, the idea, however, has old and tenacious roots in sacred texts. Hindu marriage is normatively endogamous, and inter-caste marriages are as much an offence to social morality as inter community marriages are. In practice, marriages between dalit and non-dalit castes fetch as harsh penalties as Hindu-Muslim marriages do. But, interestingly, they are not publicly ostracized nor stigmatized by a negative naming since, in Hindutva rhetoric, all Hindus share an organic indivisible unity. Cross caste marriages, therefore, cannot generate political campaigns which inter-community marriages do.

Inter-caste and inter-community civil marriages were legalized in India only after a long and protracted struggle. Though a very limited form of civil marriages -wherein couples could marry across caste and communities only by publicly abjuring their faith- was allowed from 1872, Hindus, staying within their religious fold, were allowed to marry across caste and community only after Independence. B.R. Ambedkar, great Dalit leader and the first Law Minister of India, eradicated all restrictions in his reform of Hindu Personal Laws, producing a most intense backlash from the Hindu Mahasabha, RSS, from even some Congress politicians, and from public opinion in general. Love Jihad thus builds on entrenched social values. It melds family with community and state regulations to construct a monolith of absolute power.

The discourse on Love Jihad has larger political functions within the community. It represents the Hindu woman as innocent and rather foolish, unable to differentiate between love and seduction. She, therefore, is not capable of making her own choices but needs perpetual surveillance. With a dense and visceral narrative of Muslim lust, cruelty and oppression, a tissue of lies propagated by the VHP propaganda machinery and large sections of the media, this belief sinks deep into the consciousness of Hindu women. At the same time, as I mentioned before, a 
surprisingly large number of women still assert their love in court even after they have mentioned abduction earlier: this requires stronger measures. In the Hadiya case, therefore, the Kerala High Court, as advised by the National Investigation Agency, denied the possibility of her free will altogether on the ground that Muslim organizations have "brainwashed" her so thoroughly that nothing now remains of her true will. This is a dangerous ploy that can be used against all women who may defy the state or family in any way.

And it is not women alone who are rendered subjects of family discipline. Forbidding intercommunity love is a very important first step in preserving family controls and constraints over marriages and over the autonomy of young people in general, men as well as women. In its broadest sense, therefore, anti Love Jihad campaigns are a mode of production and reproduction of ideal citizens of Hindu Rashtra: docile, unquestioning, obedient to all commands, whether emanating from religious majoritarianism, or social hierarchies and injustice —or political authoritarianism.

The deeper agenda of Hindutva is not, perhaps, simply the disinheritance of Indian Muslim or Christian citizens alone, though that too is extremely crucial. But it is to renovate and reinforce hierarchical values of caste, gender and class for Hindus, on a new basis. For a community, riven by asymmetries, power and marginalization, the figure of an alien enemy is essential to keep the internal power lines intact and preserve the semblance of an organic, seamless community. Savarkar had realized it nearly a century back. 


\section{REFERENCES}

\section{A) Bibliography}

"Citizens Against Hate." "Report on Lynchings and Religiously Motivated Vigilante Violence." South Asia Citizen's Web, September 2017. http://www.sacw.net/article13487.html. Accesseed 16 February 2018.

Agarwal, P. "Surat, Savara, Draupadi: Legitimising Rape As A Political Weapon," in T. Sarkar and U. Butalia, eds., Women and the Hindu Right. Kali for Women, Delhi, 1995.

Bachnetta, Paula. "Hindu Nationalist Women as Ideologues," in K. Jayawardena and M. de. Alwis, eds., Communalizing Women's Sexuality in South Asia. Zed Books, 1996.

Basu, Amrita. Violent Conjuncture in Democratic India. Cambridge University Press, 2015.

Basu, Tapan and Tanika Sarkar. Khaki Shorts and Saffron Flags: A Critique of Hindutva. Orient Longman, 1993.

BleE, K.M. Women of the Ku Klux Klan: Racism and Gender in the 1920s, University of California Press, 1991.

Chatterjee, Angana. Violent Gods: Hindu Nationalism in India's Present; Narratives from Orissa. Three Essays Collective, 2009.

Dixit, Neha. 'Holier than Cow', Outlook Magazine, 28 January 2013. https://www.outlookindia. com/magazine/story/holier-than-cow/283593. Accessed 16 February 2018.

_ “Exposing Love Jihad,” neha.dixit.blogspot.in of October, 2014.

"Love Jihad Or War Against Romance in India" in http://www.www.aljazeera.com/indepth, October, 14, 2014.

Bhatnagar, G.V. "BJP, RSS Caught Using Love Jihad Bogey to Fuel Communal Polarization.” The Wire, 5 October, 2015. https://www.thewire.in/12409/bjp-rss-leaders-caught-using-lovejihad-bogey-to-fuel-communal-polarisation/. Accessed 16 February 2018.

Golwalkar, M.S. We, Or Our Nationhood Defined, Bharat Prakashan, 1938.

Jaffrelot, Christophe ed., The Sangh Parivar: A Reader, Oxford University Press, 2005.

Hindu Nationalism: A Reader Permanent Black, 2007.

Khalid, Umar. “Gauri Lankesh: The Life Before Death.” The Wire, 30 November 2017. https://www. thewire.in/200886/gauri-lankesh-life-death/. Accessed 18 February 2018.

Krishnan, Kavitha. "Hadiya's Choices." The Indian Express, 30 November, 2017. http://www. indianexpress.com/article/opinion/columns/hadiyas-choices-kerala-conversion-case-islamhindu-marriage-4960951/. Accessed 18 February 2018.

Liang, Lawrence. "A Short Summary of the Law of Sedition in India." The Wire, 13 February 2016. https://www.thewire.in/21472/a-short-summary-of-the-law-of-sedition-in-india/. Accessed 18 February 2018.

Khan, Mohammad Aamir, with Nandita Haksar. Framed As A Terrorist: My 14 Year Struggle to Prove My Innocence. Speaking Tiger, 2016.

Klein, Naomi. The Shock Doctrine: The Rise of Disaster Capitalism. Picador, 2008. 
Mannvi. "Why India Shouldn't Forget Graham Staines," The Quint. 23 January, 2017. https://www. thequint.com/explainers/why-india-shouldnt-forget-graham-staines-murder-gladys-stainesdara-singh-bajrang-dal-christianity-odisha-saibo. Accessed 18 February 2018.

Mander, Harsh. "A Report from Karwaan e Mohabbat.” Daily O, 19 September 2017.

Mathur, Shubh. The Everyday Life of Hindu Nationalism: An Ethnographic Account. Three Essays Collective, 2008.

NAIR, Shalini. “Don't Criminalise Marital Rape, May Disturb Institution of Marriage: Government." The Indian Express, 30 August, 2017. http://www.indianexpress.com/article/india/dontcriminalise-marital-rape-may-disturb-institution-of-marriage-government-4819707/. Accessed 16 February 2018.

Pandey, Gyanendra. The Construction of Communalism in Colonial North India. Oxford University Press, 1990.

SARkar, Radha and Amar SArkar. "Sacred Slaughter: An Analysis of Historical, Communal and Constitutional Aspects of Beef Bans in India," Politics, Religion and Ideology, Routledge, 28 November 2016.

SARKar, Sumit. Modern India, Macmillan, 1983.

Sarkar Tanika and Urvashi Butalia, eds. Women and the Hindu Right. Kali for Women, 1995.

SARKar, Tanika. "Heroic Women, Mother Goddesses," in Tanika Sarkar and Urvashi Butalia, eds, Women and the Hindu Right. Kali for Women, 1995.

"The Gender Predicament of the Hindu Right," in K.N. Panikkar, ed., The Concerned Indian's Guide to Communalism, Penguin, 1999.

"The Gender Predicament of the Hindu Right," in Jaffrelot, Christophe ed.. The Sangh Parivar: A Reader. Oxford University Press, 2005.

"Hindutva's Hunduism," in J.Zavos, P. Kanungo, D. Reddy, M. Warrior and R. Williams, eds, Public Hinduisms. Sage, 2012.

Savarkar, V.D. Hindutva: Who Is A Hindu? Bharatiya Sadan, 1989 (1923).

TYagI, Aastha. "Sadhana Karti Chalein: Deconstructing Rashtrasevika samiti’s Ideology," unpublished MPhil dissertation, Department of Sociology, University of Delhi, 2017.

Vanayak, Achin. “The Enemy Within,” Sunday Review, 16 November, 1990.

_- Hindutva Rising: Secular Claims, Communal Realities, Tulika, 2007.

\section{B) Filmography}

“Rohith Vemula-An Unfinished Portrait." Uploaded by Ajay Kumar Koli. YouTube, 28 January 2016. http://www.youtube.com/watch?v=c2PWd1hzHc8. Accessed 16 February 2018.

The World Before Her. Dir Nisha Pahuja. Storyline Entertainment, 2013. 
